\title{
'Shake It Up' as Android Mobile Learning Application based on Earthquake Mitigation for Junior High School Students
}

\author{
Gita Sukmawati ${ }^{1}$, Eka Cahya Prima $^{2}$, Eliyawati $^{3}$ \\ \{gitaskm@gmail.com¹, ekacahyaprima@upi.edu², eliyawati@upi.edu ${ }^{3}$ \} \\ Department of Science Education, Faculty of Mathematics and Science Education, Universitas \\ Pendidikan Indonesia, Bandung, Indonesia ${ }^{1,2,3}$
}

\begin{abstract}
Indonesia is situated in a geologically unstable area called the Pacific Ring of Fire which faces the risk of powerful earthquakes with potentially devastating effects. The most effective measure to be taken against earthquake and other natural disaster is knowing what to do when it happens. This issue intended the researcher to build a mobile learning application for earthquake mitigation using game-engine software called Unity The subject was 30 students of Junior High School in Bandung and one science teacher. The experts have evaluated content, language, and artwork in the mobile learning application. The findings indicate that from every aspect, the general mobile learning application based on Earthquake Mitigation is received very positive feedback. For its implementation, students and science educators are immensely welcomed.
\end{abstract}

Keywords: Earthquake. Mitigation of earthquake. Pacific Ring of Fire. Mobile learning.

\section{Introduction}

Preparedness is a significant factor in nations that are susceptible to disasters. There are various disaster management approaches. However, one common point of these approaches is that they are "preventive." There are several components to this preventive approach, the first and foremost of which are preparedness and education. These preventive efforts can open up the possibility of capacity building in dealing with disasters which shows variations in the period and time of development. This preventive approach process also drags uncertainty by increasing awareness of all components, individuals, and communities by the source of common problems in dealing with disasters [1]. Humans cannot control Earthquakes, but it comes from natural disasters that can eliminate lives and property in a short time. Earthquake is something that cannot be avoided, but by doing something to prevent the earthquake, we can at least reduce the risk [2].

Earthquake is a natural disaster. The most effective measure to be taken against earthquakes and other natural disasters are individuals knowing what to do to save themselves [3]. An earthquake is said to be a disaster that damages both private and public property and causes damage that hinders the pace of micro and macro scale production, infrastructure development, population development and the social structure of the country. Natural disasters similar to earthquakes can devour a city and its contents in seconds. Like the recent earthquake that has torn down houses that are still vulnerable to disasters, causing long-term 
damage. It is these damaging effects which then disrupt the running of the country's abundant budget and financial assets from post-earthquake development and rehabilitation and stabilization projects. Another consequence of earthquakes is that people lose their living space that can fulfill their daily needs [4].

Disaster risk reduction can be started from the field of education, so as an educational institution, universities can play an important role in channeling knowledge and education about the risks of these natural disasters to the community in order to achieve alertness, awareness, preparedness, and skills in survival when natural disasters occur [5].

Learning and teaching about natural disaster training require media in the delivery of information and knowledge, learning media that can be used include mobile computing devices such as smartphones, mobile phones, tablet computers, e-readers, and other devices that can assist learning. The enthusiasm of people increases over time with the depiction, design, implementation, and evaluation of how mobile computing devices can facilitate education, training and support the performance of this natural disaster training [6]. The use of this type of smartphone that is quite loved by people around the world today is Android. Since being bought by Google, Android has experienced very rapid growth. In September 2012, Android users had reached 200 million, and more than 295,000 applications were available on the Play Store. Android is open source so that anyone can create apps for Android and can sell them on the Play Store [7],[8]. Considering the ease and sophistication offered by Android as a smartphone that can provide learning media through mobile applications, the learning methods regarding earthquake mitigation will be more easily accessible and accepted by Junior High School students.

This study aims to develop Android Apps about mitigation tectonic and volcanic Earthquakes for Junior High Schools. Therefore, the researcher decided to conduct the research titled "Development of Android Mobile Learning Application in Mitigation of Earthquake for Junior High School."

\section{Research Method}

This research method that will be used in this research is developmental research. The approach can explain the instrument and app development process in these studies and consequently evaluate readability and validity. Developmental research provides different models, tools, and techniques to be studied. The method is separated into several phases where the reporting and analysis of information are involved in each stage.

This research method is suitable for the research, which is to develop mobile learning android application in mitigation of earthquake for junior high school students because the study focuses on the development process of both instrument and application rather than merely gathering data.

The researcher created mobile learning in the form of an Android application in the mitigation of earthquake topic. Final paper supervisors then supervised the mobile learning application before the experts that expertize in content (Geography), language (English), and artwork (IT) assess it. After a sequence of suggestions and revisions until the final assessment, the mobile learning application was brought to science teachers and students to be reviewed. The subject of this study were three experts in each aspect: science content, language, and artwork (IT) for the validation of mobile learning applications. Experts with a background 
based on each of their expertise will assess these various aspects. For mobile learning application impressions, Junior High School students will determine the media.

The location of this research is in the region of Bandung in particular. The school uses Bilingual (English \& Bahasa) as communication in the teaching-learning process. The curriculum applied in this school is the 2013 national curriculum. The population in this research will be 8th-grade students who already learn about Earthquake topics. The sample will be 30 students from Laboratorium Junior High School in Bandung who will be chosen through simple random sampling.

The instruments are used in these studies to acquire or gain the data. The tools used are expert judgment rubric and questionnaire for students and science teachers to assess the suitability of the mobile learning application and how its design met the real need for understanding in teaching dynamic electricity subject. The rubric used in this study is the Likert scale and ratings. There were two aspects to the rubric: the methods and features of developing mobile learning applications. The features are the content, the language, and the mobile learning design itself. The scale is 1 to 4 to determine whether the intention, goal, and expectations were met by the points in the mobile learning implementation. The Likert scale and ratings are also used for students' and teachers' questionnaire. A 4-rated scale was used to determine whether or not the mobile learning application is suitable and appropriate for Junior High School level. The elaborate rating scoring is in a questionnaire form.

\section{Result and Discussion}

\subsection{Design and Developmental Stage}

The materials that contained in mobile learning application based on Earthquake Mitigation are Earthquake topic specified in Indonesian Curriculum 2013. In this mobile learning application based on Earthquake Mitigation, the materials divide into some issues which are the earthquake itself, the mitigation of earthquake; before, during and after. The contents are deciphered in the teaching-learning process.

The flowchart is the illustration of story flow in the development process of mobile learning application based on Earthquake Mitigation. The flowchart is started from the initial process of using the mobile learning application until the end by the user. The storyboard is the plan of multimedia that will be developed based on the flowchart to make development stage easier. Figure 1 is an example of a storyboard from a mobile learning application based on Earthquake Mitigation. In the first page show the goals of the application. After the first page, the menu feature is shown and the user can choose the content. The sidebar menu is also provided.

The coding process is to support and make all the features work properly, such as the button that takes the user to every scene in the application. The process is done in some parts of the mobile learning application, as follows: (1) organizes each object in the overall of the application, (2) arranges the movement of the layout, (3) shows every pop-up/slide. The coding process can be seen in Figure 2.

To check the suitability of the mobile learning application in mitigation of earthquake, some experts are involved in judging the application. The first expert is on content science, the aspect that the judge is the contents' objective in line with the students' necessity, the 
accuracy of material and the interest in the content. The result of the expert content explained in Table 1.

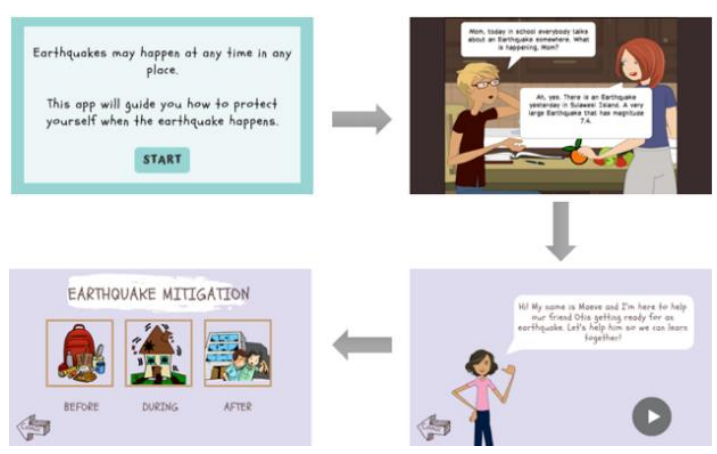

Fig. 1. The example of a storyboard scheme.

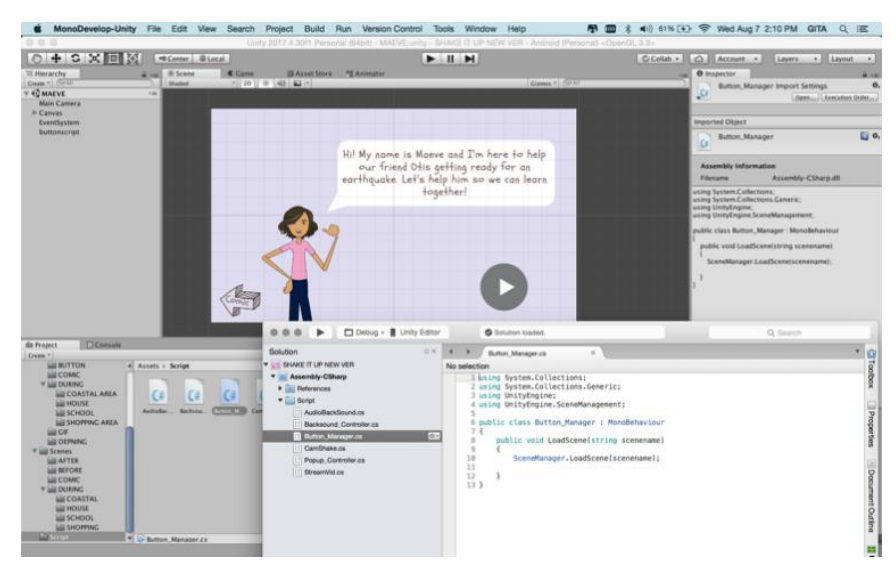

Fig. 2. The example of coding in Unity 2D.

Table 1. Experts“ judgment result on content.

\begin{tabular}{llllll}
\hline No. & Expert & Aspect & $\begin{array}{l}\text { Ideal } \\
\text { Score }\end{array}$ & $\begin{array}{l}\text { Result } \\
\text { Score }\end{array}$ & $\begin{array}{l}\text { Percentage } \\
(\%)\end{array}$ \\
\hline 1 & Content & $\begin{array}{l}\text { Appropiate } \\
\text { level } \\
\text { detail }\end{array}$ & 4 & 4 & 100 \\
& $\begin{array}{l}\text { Balance } \\
\text { Presentation } \\
\text { of Idea }\end{array}$ & 4 & 3 & 75 \\
Accuracy & 4 & 3 & 75 \\
Average Score & & & & $83.333 \%$ \\
\hline
\end{tabular}

The result of the content judgment from the expert is concerned about the accuracy and balanced presentation of the idea indicator. The relevant detail of the content itself is excellent. All the information that is in the apps gives the students opportunities to learn a lot of new 
insight about the topic. Some of the content should be more reliable and accurate. It can be seen by the percentage that is given by the expert.

The aspect that judge by the language expert is the vocabulary, diction and grammar \& spelling. The result can be seen in Table 2. Based on the table above, the average percentage of expert's judgment on language is $87.5 \%$ which is categorized as "Very Good". The aspect that is highlighted in the grammar \& spelling given $100 \%$. The diction used in the materials are exact and wisely used to avoid misunderstand explanation. The percentage of the diction aspect is given $75 \%$. The vocabulary considered to be new to most of the students and it given $87.5 \%$ by the experts.

The Navigation, Screen Design, User-friendly, and Aesthetic are the aspects that judged by Artwork (IT) experts. The result of judgment is shown in Table 3.

Table 2. Experts‘ Judgment Result on Language.

\begin{tabular}{clllll}
\hline $\begin{array}{c}\text { No } \\
.\end{array}$ & Expert & Aspect & $\begin{array}{l}\text { Ideal } \\
\text { Score }\end{array}$ & $\begin{array}{l}\text { Result } \\
\text { Score }\end{array}$ & $\begin{array}{l}\text { Percentage } \\
(\%)\end{array}$ \\
\hline 1 & Languag & Vocabulary & 4 & 3.5 & 87.5 \\
& e & $\begin{array}{l}\text { Diction } \\
\text { Grammar }\end{array}$ & 4 & 3 & 75 \\
& & & & 100 \\
& & Spelling' & 4 & 4 & \\
& & & &
\end{tabular}

Average Score

$87.5 \%$

Table 3. Experts‘ judgment result in artwork.

\begin{tabular}{clllll}
\hline No & Expert & Aspect & $\begin{array}{l}\text { Ideal } \\
\text { Score }\end{array}$ & $\begin{array}{l}\text { Result } \\
\text { Score }\end{array}$ & $\begin{array}{l}\text { Percentage } \\
(\%)\end{array}$ \\
\hline 1 & Artwork & $\begin{array}{l}\text { Navigation } \\
\text { Screen }\end{array}$ & 4 & 3 & 75 \\
& & $\begin{array}{l}\text { Design } \\
\text { User- } \\
\text { friendly }\end{array}$ & 4 & 4 & 100 \\
& & Aesthetic & 4 & 4 & 100 \\
Average Score & & & & $93.75 \%$ \\
\hline
\end{tabular}

Based on Table 3, there is some aspect that judged by the experts on Artwork such as navigation that leads the user to use the application. The percentage of navigation used in the application is $75 \%$ which represents that several things should be done to improve the app. The screen design such as the fonts, color, graphics-interface used in the application has quite a high percentage which is in the range of $100 \%$. The apps can be run by the students without the teacher supervision which represents the user-friendly aspect in $100 \%$. The last element is aesthetic which represents the level of artistry, style, and animation. This aspect also has quite a high percentage which is $100 \%$. Overall, the average percentage given by the expert on all aspects is $93.75 \%$ which classified in the "Very Good" category. 


\subsection{Implementation Stage}

Based on Table 4, some aspects categorize on a "Very Good" scale that has a percentage range from $76 \%-100 \%$. The dimensions are mobile connectivity with $100 \%$ which represents the accessibility of the materials, the convenient and the time effectivity in using the mobile application. The materials also have a high score which $100 \%$, the science considered that the elements in the app are understandable. The mobile layout scored $91 \%$; there is one aspect that did not have a perfect score which needs an improvement in the media that should support all the material comprehension. The last elements are personalized learning experiences which scored $100 \%$. The science teacher considered that mobile learning application is such meaningful learning for the students and can give advantages to create personalized learning.

Table 4. The result of science teachers' and students' responses on Shake It Up.

\begin{tabular}{|c|c|c|c|c|c|}
\hline Category & Statement & \multicolumn{2}{|c|}{ Teacher score } & \multicolumn{2}{|c|}{ Student Score } \\
\hline $\begin{array}{l}\text { Mobile } \\
\text { Connectivity }\end{array}$ & $\begin{array}{l}\text { The application was a convenient and } \\
\text { sufficient time to consume. } \\
\text { Easy to connect. } \\
\text { The materials are accessible. }\end{array}$ & 100 & Very Good & 77.5 & Very Good \\
\hline Materials & Materials are understandable & 100 & Good & 75 & Good \\
\hline $\begin{array}{l}\text { Mobile } \\
\text { Layout }\end{array}$ & $\begin{array}{l}\text { The appearance is attractive. } \\
\text { All text is seen and readable. } \\
\text { All media are supported the material } \\
\text { comprehension. }\end{array}$ & 91 & Good & 77.5 & Very Good \\
\hline $\begin{array}{l}\text { Personalized } \\
\text { Learning } \\
\text { Experience }\end{array}$ & $\begin{array}{l}\text { Mobile learning application is such a } \\
\text { meaningful learning } \\
\text { Gives advantages to create personalized } \\
\text { learning }\end{array}$ & 100 & Very Good & 77.7 & Very Good \\
\hline & Overall & 97.5 & Very Good & 76.4 & Very Good \\
\hline
\end{tabular}

This mobile learning application is interesting for students and helps them build knowledge knowing what-to-do in an earthquake. Kiger et al. [8] indicated that mobile technology could have a beneficial effect when it designed, implemented and correctly developed to meet the 21st-century period when it is necessary to create the digital age accessible to everyone, at any time and an affordable price. Based on the results and the evaluation of this mobile app by the experts, science teacher, and junior high school students, the mobile application can acquire an interest in learning earthquake mitigation. There are some benefits to this learning method by actually implementing this mobile learning application as an enriching source besides the primary textbook. The use of M-learning declares various chances to engage a set of knowledge widely, context construction beyond the formal educational set up [9] 


\section{Conclusion}

According to all evaluations conducted by experts, science teachers, and Junior High School students, this mobile learning application 'Shake It Up' has received positive responses. For future work, the upgrade version of this application has to build with includes precious materials and a better flow of learning delivery.

\section{References}

[1] Gerdan, S.: Determination of disaster awareness, attitude levels and individual priorities at Kocaeli University. Eurasian Journal of Educational Research. vol 55, pp. 159-176 (2014)

[2] Cherner, T., Lee, C. Y., Fegely, A. and Santaniello, L.: A detailed rubric for assessing the quality of teacher resource apps. Journal of Information Technology Education: Innovations in Practice., G., de Laat, M., Dillon, T., \& Darby, J. JISC LXP Student experiences of technologies Final report. Higher Education Funding Council for England. pp. 1-104 (2016)

[3] Fetihi, L. and Gülay, H.: The Effect of Earthquake Awareness Development Program (EADP) on 6 Years Old Children. International Online Journal of Educational Sciences. Vol. 3(2), pp. 663-678 (2011)

[4] Baytiyeh, H.: Developing effective earthquake risk reduction strategies: The potential role of academic institutions in Lebanon. Prospects. Vol. 45(2), pp. 245-258 (2015)

[5] Shaw, R., Shiwaku Hirohide Kobayashi, K. and Kobayashi, M.: Linking experience, education, perception, and earthquake preparedness. Disaster Prevention and Management, Vol. 13 No. 1, pp. 39-49 (2004)

[6] Çelik, S., Atak, H., \& Erguzen, A.: The effect of personality on cyberbullying among university students in Turkey. Eurasian Journal of Educational Research. Vol. 49, pp. 129-150 (2012)

[7] Maiyana, E.: Pemanfaatan Android Dalam Perancangan Aplikasi Kumpulan Doa. Jurnal Sains dan Informatika: Research of Science and Informatic. vol 4(1), pp. 54-65 (2018)

[8] Kiger, D., Herro, D. and Prunty, D.: Examining the influence of a mobile learning intervention on third-grade math achievement. Journal of Research on Technology in Education. Vol 45(1), pp. 61-82 (2012)

[9] Dyson, T.: Population and development: the demographic transition. Zed Books Ltd. (2013) 